\title{
PENGEMBANGAN MEDIA PEMBELAJARAN BERBASIS MULTIMEDIA GERAKAN DASAR TARI BALI
}

\author{
Oleh \\ Ni Ketut Kertiasih \\ Jurusan Manajemen Informatika, FTK - Undiksha
}

\begin{abstract}
Abstrak
Media sangat dibutuhkan dalam proses pembelajaran untuk membantu pencapaian tujuan pembelajaran. Salah satu muatan lokal dalam kurikulum Sekolah Menengah Pertama adalah seni tari. Pengembangan media pembelajaran berbasis multimedia ini dapat dijadikan sebagai media dalam mempelajari gerakan dasar tari Bali. Dengan demikian, dalam proses mengeksplorasi gerakan dasar tari yang tidak dibatasi oleh tempat dan waktu. Ini berarti bahwa siswa dapat belajar gerakan dasar tari Bali kapanpun dan dimanapun. Media pembelajaran yang dikembangkan tersebut dikemas dalam bentuk CD interaktif. Media pembelajaran tersebut dapat memudahkan dalam penguasaan gerakan dasar tari Bali yang meliputi agem, tandang, dan tangkep. Dengan demikian, mempelajari gerakan dasar tari Bali dilakukan tidak hanya di sekolah atau sanggar tari, melainkan juga dapat dilakukan di rumah.
\end{abstract}

Kata kunci: media pembelajaran, multimedia, dasar tari Bali

\begin{abstract}
Media is needed in the learning process to help achieve learning objectives. One local content in the secondary school curriculum is the art of dance. Development of multimedia-based instructional media can be used as a medium in learning the basic movements of dance of Bali. Thus, in the process explore the basic dance movements that are not constrained by time and place. This means that students can learn basic movements of Balinese dance whenever and wherever. Instructional media developed is packaged in the form of an interactive CD. Instructional media can facilitate in mastering basic movements of Balinese dance which includes agem, tandang, dan tangkep. Thus, learning the basic movements of Balinese dance performed not only at school or dance studio, but also can be done at home.
\end{abstract}

Key words: instructional media, multimedia, basci of Balinese dance 


\section{PENDAHULUAN}

Indonesia memiliki keanekaragaman adat istiadat, tata krama, pergaulan, kesenian, bahasa, keindahan alam dan ketrampilan lokal yang merupakan ciri khas suatu suku bangsa. Keanekaragaman tersebut memperindah dan memperkaya nilai-nilai kehidupan bangsa Indonesia. Oleh karena itu, keanekaragaman tersebut perlu diusahakan pengembangan dan pelestariannya dengan tetap mempertahankannya melalui upaya pendidikan. Pengenalan keadaan lingkungan alam sosial dan budaya kepada peserta didik di sekolah memberikan kemungkinan besar untuk akrab dengan lingkungan dan terhindar dari keterasingan terhadap lingkungan serta dapat menolong dirinya sendiri dalam rangka memenuhi kebutuhan hidupnya.

Tari tradisional Bali awalnya hanya berdasarkan pada pemujaan dan persembahyangan dengan menggerakkan mata, kepala, tangan dan kaki serta tubuh dengan berirama untuk mengekspresikan perasaannya terhadap Tuhan yang dipuja di setiap hati sanubari masyarakat Bali pada khususnya. Masyarakat Bali, pada zaman dahulu mewajibkan anakanaknya untuk belajar Tari tradisional Bali, namun pada zaman sekarang anak-anak relatif sedikit yang mau belajar tari tradisional Bali. Hal tersebut diakibatkan oleh masuknya budaya barat ke Bali. Hal tersebut mengakibatkan berkurangnya sebagian minat anak-anak untuk mempelajari tari Bali, sehingga akan berdampak terhadap pelestarian budaya Bali.

Untuk meningkatkan kembali minat anak-anak dalam mempelajari tari Bali di sekolah pelajaran seni tari Bali sebagai muatan lokal pilihan diberikan kepada semua siswa. Dimana muatan lokal yaitu bahan kajian dan pelajarannya ditetapkan di Daerah dan disesuaikan dengan lingkungan, sosial budaya serta kehidupan Daerah (Depdikbud, 1994). Mutu pendidikan khususnya pendidikan seni tari Bali, tentunya tidak bisa lepas dari tiga faktor, yaitu sekolah sebagai tempat 
terlaksananya pendidikan, guru sebagai pelaksana dan siswa sebagai peserta pendidikan. Ketiga faktor tersebut menjadi kurang berarti meskipun sudah disiapkan dengan baik, jika penyampaian materi pelajaran guru menggunakan metoda atau cara yang kurang tepat.

Selain sebagai muatan lokal untuk mempelajari tari Bali dapat dilakukan di sanggar tari atau tempat belajar tari. Belajar tari Bali memungkinkan terjadinya interaksi langsung antara pelatih dengan siswa. Apabila siswa mendapatkan kesulitan dalam mempelajari tari Bali maka siswa tersebut akan mendapat bimbingan secara langung dari pelatih. Di sisi lain karena adanya keterikatan tempat dan waktu menyulitkan anakanak untuk memperdalam dasar-dasar tari Bali. Sehingga untuk mengatasi keterikatan tempat dan waktu tersebut diperlukan media sebagai panduan untuk mempelajari dasar-dasar tari Bali sehingga tidak terikat dengan tempat dan waktu, sehingga dengan media tersebut dapat mempelajari kapan pun dan di manapun keinginan untuk mempelajari dasar-dasar tari Bali. Dengan demikian perlu dikembangkan media pembelajaran berbasis multimedia yang dapat digunakan sebagai panduan dalam mempelajari dasar-dasar tari Bali. Media yang dikembangkan tersebut dikemas dalam bentuk CD interaktif.

Komputer sekarang ini merupakan media informasi yang sudah menjadi media yang handal. Kehandalan komputer mengalahkan kemampuan buku atau media cetak lainnya. Buku atau media cetak lainnya hanya dapat memberi petunjuk dengan tulisan atau gambar saja. Gambar-gambar gerakan tari yang dicontohkan dalam buku kurang menarik dan kurang dapat dipahami maksud gerakan suatu tarian, bila dibandingkan gerakan suatu tarian yang dicontohkan melalui suatu media yang berbasis multimedia. Dengan multimedia gerakan dasar tari Bali, anak-anak dapat menentukan sendiri suasana belajar, waktu dan tempat yang dikehendaki oleh anak-anak untuk mempelajari dasar-dasar tari Bali. Multimedia ini dirancang dengan tampilan yang sedemikian rupa sehingga anak-anak dengan leluasa dapat mempelajari dasar-dasar tari 
Bali, walaupun tidak didampingi oleh pelatih atau guru tari. Sehingga untuk menjaga kelestarian seni budaya dalam hal ini khususnya tari Bali tetap dapat terjaga dengan baik melalui anak-anak sebagai generasi penerus bangsa. Melalui multimedia ini, tidak saja hanya anak-anak saja yang dapat mempergunakannya untuk melatih diri dalam menguasai gerakan dasar tari Bali. Siapapun juga yang berkeinginan untuk mempelajari gerakan dasar tari Bali dapat mempelajarinya dengan mudah karena multimedia ini dikemas dalam bentuk CD interaktif.

\section{LANDASAN TEORI}

\subsection{Pengertian Media Pembelajaran}

Azhar (2005) mengatakan bahwa media apabila dipahami secara garis besar adalah manusia, materi, atau kejadian yang membangun kondisi yang membuat siswa mampu memperoleh pengetahuan, keterampilan atau sikap. Dalam pengertian ini, pendidik, buku teks dan lingkungan merupakan media.

Azhar (2005) mengemukakan istilah medium sebagai perantara yang mengantar informasi antara sumber dan penerima. Jadi, televisi, film, radio, rekaman audio, foto, gambar yang diproyeksikan, bahanbahan cetakan, dan sejenisnya adalah media komunikasi. Apabila media ini membawa pesan-pesan atau informasi yang bertujuan instruksional atau mengandung maksud-maksud pengajaran maka media itu disebut media pembelajaran. Batasan media sebagai semua bentuk perantara yang digunakan oleh manusia untuk menyampaikan atau menyebar ide, gagasan, atau pendapat sehingga ide, gagasan, atau pendapat yang dikemukakan itu sampai kepada penerima yang dituju.

Dalam proses pembelajaran, sering pula memakai kata media pembelajaran atau digantikan dengan istilah-istilah seperti alat pandangdengar, bahan pengajaran (instructional material), komunikasi pandangdengar (audio-visual communication), pendidikan alat peraga pandang 
(visual education), teknologi pendidikan (educational technology), alat peraga dan media penjelasan. Sesuai pendapat tersebut, dalam hal ini media yang dimaksud adalah sebuah perangkat lunak yang tersimpan dalam bentuk CD (Compact Disc) yang digunakan sebagai alternatif sumber belajar sehingga dapat merangsang pikiran, perasaan dan minat peserta didik untuk memperhatikan pelajaran yang diberikan oleh pengajar sedemikian rupa sehingga proses belajar menjadi lebih baik.

Berdasarkan uraian beberapa batasan tentang media di atas, Azhar (2005) mengemukakan ciri-ciri umum yang terkandung pada setiap batasan itu.

a. Media pendidikan memiliki pengertian fisik yang dewasa ini dikenal sebagai Hardware (perangkat keras), yaitu suatu benda yang dapat dilihat, didengar dan diraba dengan pancaindra.

b. Media pendidikan memiliki pengertian nonfisik yang dikenal sebagai Software (perangkat lunak), yaitu kandungan pesan yang terdapat dalam perangkat keras yang merupakan isi yang ingin disampaikan kepada siswa.

c. Penekanan media pendidikan terdapat pada visual dan audio.

d. Media pendidikan memiliki pengertian alat bantu pada proses belajar baik di dalam maupun di luar kelas.

e. Media pendidikan digunakan dalam rangka komunikasi dan interaksi guru dan siswa dalam proses pembelajaran.

f. Media pendidikan dapat digunakan secara massal (misalnya: radio, televisi), kelompok besar dan kelompok kecil (misalnya: film, slide, vidio, OHP), atau perorangan (misalnya: modul, komputer, radio tape/kaset, vidio recorder).

g. Sikap, perbuatan, organisasi, strategi, dan manajemen yang berhubungan dengan penerapan suatu ilmu. 


\subsection{Manfaat Penggunaan Media dalam Pembelajaran}

Secara umum media mempunyai manfaat sebagai berikut.

a. Memperjelas penyajian suatu pesan agar tidak terlalu bersifat verbalistis.

b. Mengatasi keterbatasan ruang, waktu dan daya indera seperti

- obyek yang terlalu besar, dapat digantikan dengan realita, gambar, film bingkai, film, gambar video, atau model

- obyek yang kecil dibantu dengan proyektor mikro, film slide, gambar video atau gambar

- gerak yang terlalu lambat atau terlalu cepat dapat dibantu dengan timelapse, highspeed photografi atau slow motion playback video

- kejadian atau peristiwa yang terjadi pada masa lalu dapat ditampilkan lagi melalui rekaman film, video, atau foto

- Obyek yang terlalu kompleks dapat disajikan dengan model, diagram, dll

- Konsep yang terlalu luas dapat divisualkan dalam bentuk film, slide, gambar atau video

c. Dengan menggunakan media secara tepat dan bervariasi dapat mengatasi sikap pasif siswa. Dalam hal ini media berguna untuk:

- menimbulkan gairah belajar,

- memungkinkan interaksi langsung antara siswa dengan lingkungan dan kenyataan,

- memungkinkan siswa belajar sendiri menurut minat dan kemampuannya

d. Dengan sifat yang unik pada siswa juga dengan lingkungan dan pengalaman yang berbeda-beda, sedangkan kurikulum dan materi pembelajaran yang sama untuk setiap siswa, masalah ini dapat diatasi dengan media pembelajaran dalam kemampuannya:

- memberikan perangsang yang sama,

- menyamakan pengalaman,

- menimbulkan persepsi yang sama. 


\subsection{Tari Tradisional Bali}

Tari Bali adalah cabang seni pertunjukkan yang mengandung dan dijiwai oleh nilai-nilai budaya Hindu-Bali. Di dalam tari Bali menyatu nilai-nilai estetik dan asrtistik yang diikat oleh nilai-nilai Budaya yang didasari oleh agama Hindu-Bali. Demikian eratnya kaitan kesenian dengan kehidpan keagamaan warga setempat. Semua tari Bali, apapun bentuknya, menjadi kesenian bernuansa religius/spiritual (Dinas Kebudayaan, 2002).

Tari Bali, secara luas dapat diartikan bahwa tidak terlepas kalau membicarakan masalah gaya atau style. Sedangkan gaya itu tidak lain daripada pengungkapan watak perorangan, periode sejarah, dari satu sekolah atau group individu. Dalam tari terdapat unsur-unsur/elemenelemen tari seperti: gerak, ritme dan ruang (Bandem, dkk, 1985).

Menurut Bandem (1985) orang-orang Indonesia dengan mudah dapat membedakan antara tari Bali dengan tari lainnya di Indonesia. Hal ini disebabkan karena di dalam tari Bali terdapat perbendaharaan gerak atau ugel-ugel tari yang sangat unik. Tari Bali sangat ekspresif dimana ungkapan air muka sangat diutamakan. Melalui perubahan air muka dapat diungkapkan beberapa rasa didalam tari seperti rasa sedih, gembira, lucu, cinta malu, marah dan lain sebagainya. Seledet adalah merupakan unsur pokok didalam tari Bali, tanpa seledet dan ungkapan air muka itu, tari Bali tidak hidup sama sekali.

Di Bali banyak terdapat jenis tari, yang dapat dilihat dari berbagai hal. Salah satunya adalah berdasarkan fungsi tari tersebut. Dilihat dari fungsinya, tari Bali dapat diklasifikasikan menjadi tiga yaitu tari wali, bebali, dan balih-balihan. Tari wali adalah seni tari wali (sakral, religius) yaitu seni tari yang dilakukan di pura-pura atau tempat-tempat yang berhubungan dengan agama dan upakara agama, sebagai pelaksana upacara atau upakara dan pada umumnya tidak memakai lakon. Yang termasuk ke dalam tari wali adalah tari rejang, tari Sang Hyang. Tari bebali adalah seni tari yang berfungsi sebagai pengiring upacara atau 
upakara yang umumnya memakai lakon, seperti misalnya: wayang wong dan parwa, topeng, gambuh. Sedangkan tari balih-balihan adalah segala jenis tari yang mempunyai fungsi sebagai seni hiburan, seperti tari legong kraton, joged, janger. (Bandem, 1983)

\subsection{Gerakan Dasar Tari Bali}

Sebelum belajar tari Bali, penari terlebih dahulu belajar tari senam/dasar. Tari senam adalah untuk melemaskan otot-otot dan persendian tubuh sebagai gerak pendahuluan ketika mulai belajar menari. Hal ini penting karena dapat dipakai untuk mengatasi gerakan-gerakan yang kaku. Tari Bali memiliki banyak gerakan dasar. Gerakan dasar ini dipelajari sebelum si penari belajar tari Bali. Dasar-dasar tari Bali berfungsi untuk membekali seorang penari dasar gerakan tari Bali. Secara garis besar dasar tari Bali ada tiga, yaitu: agem, tandang,d an tangkep.

a. Agem

Agem merupakan sikap atau cara pokok berdiri. Posisi kaki kanan dan kiri sama-sama serong menyudut, tumit salig bertemu. Kedua tangan diangkat menyiku dengan siku sejajar pundak, telapak tangan menghadap ke depan, jari-jari tangan berdiri tegak serta kedua ibu jari merapat ke telapak tangan. Agem ada dua jenis yaitu agem kanan dan agem kiri.

\section{b. Tandang}

Tandang merupakan suatu cara untuk menggerakkan suatu gerakan yang baru sehingga menjadi rangkaian gerakan yang bersambung. Yang termasuk tandang adalah:

- seledet dan ngelier, merupakan gerakan mata,

- nyregseg, gerakan kaki yang dilakukan dengan cepat ke samping kiri dan kanan dalam keadaan menjinjit,

- malpal, gerakan kaki berjalan cepat,

- uluwangsul, gerakan menggelengkan leher dengan lembut. 
c. Tangkep.

Tangkep merupakan gerak atau perubahan air muka atau perubahan gerak indra yang terdapat pada wajah dan kepala. Yang termasuk tangkep yaitu:

- kenyem (senyum), ungkapan rasa halus yang manis diwujudkan pada bibir,

- dedeling, ekspresi wajah yang menggambarkan mimik marah.

\section{Desain Pengembangan Media Pembelajaran Berbasis} Multimedia Gerakan Dasar Tari Bali

Untuk pengembangan media pembelajaran berbasis multimedia gerakan dasar tari Bali ini menggunakan model desain pengembangan yaitu model ADDIE, yang meliputi 5 tahap pengembangan seperti terlihat pada Gambar 1.

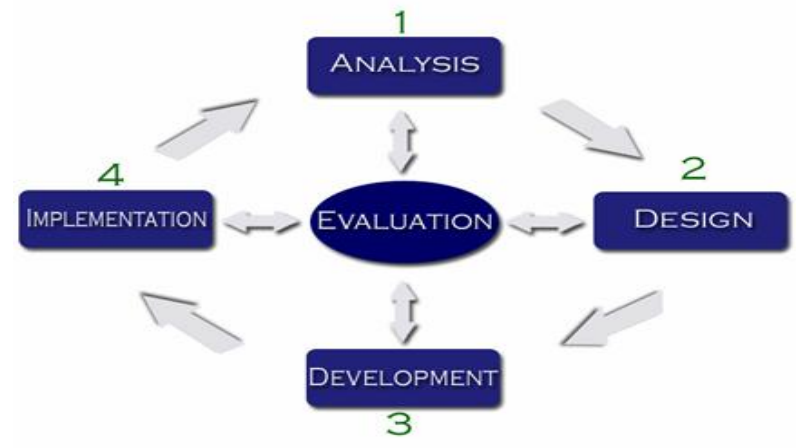

Gambar 1. Desain Pengembangan Media Pembelajaran Model ADDIE

a. Tahap 1: Analysis, pada tahap ini adalah suatu langkah untuk mengidentifikasi masalah, melakukan menganalisis kebutuhan dan melakukan analisis tugas, sehingga menghasilkan luaran terkait dengan karakteristik siswa, identifikasi kesenjangan, identifikasi kebutuhan dan analisis tugas yang rinci didasarkan atas kebutuhan.

b. Tahap 2: Design, pada tahap ini dilakukan perancangan dari antarmuka dari multimedia gerakan dasar tari Bali. Dengan 
memperhatikan tujuan pembelajaran yang ingin dicapai dan strategi pembelajaran sehingga rancangan antarmuka dibuat sedemikian rupa sehingga memenuhi kebutuhan dalam proses pembelajaran.

c. Tahap 3: Development, tahap ini adalah merupakan proses untuk mewujudkan rancangan tersebut menjadi kenyataan, dengan menggunakan Macromedia Flash untuk pengembangannya.

d. Tahap 4: Implementation, pada tahap ini adalah tahap menerapkan dari media pembelajaran yang telah dikembangkan.

e. Tahap 5: Evaluation, tahap ini adalah untuk melihat keberhasilan dari media yang dikembangkan apakah sesuai dari harapan semula. Evaluasi bertujuan untuk melakukan perbaikan terhadap media pembelajaran yang telah dikembangkan. Namun evaluasi juga dilakukan pada tahap-tahap sebelumnya, misalnya uji ahli untuk mengetahui kualitas desain media pembelajaran, serta konten media apakah sudah sesuai dengan tujuan pembelajaran yang ingin dicapai.

\section{Hasil Pengembangan Media Pembelajaran Gerakan Dasar Tari Bali}

Pengembangan media pembelajarn berbasis multimedia yang telah dikembangakan dikemas dalam bentuk CD interaktif sebagai media untuk mempelajari gerakan dasar tari Bali. Media pembelajaran tersebut dikembangkan menggunakan sofware umum yaitu Macromedia Flash. Multimedia tersebut memberikan tampilan gerakan dasar tari Bali dan tampilan contoh gerakan dasar tari Bali dengan model. Media pembelajaran ini menampilkan menu utama, di mana anak-anak yang ingin mempelajari gerakan dasar tari Bali dapat memilih materi (konsep) yang tersedia. Materi (konsep) yang ditampilkan, dapat langsung dipilih sesuai dengan urutan sub-materinya.

Beberapa contoh tampilan menu hasil dari pengembangan multimedia gerakan dasar tari Bali sebagai media dalam mempelajari gerakan dasar tari Bali adalah sebagai berikut.

JPTK, UNDIKSHA, Vol. 6, No. 1, Januari 2009 : 37 - 50 


\section{SELAMAAT BELAJAR DASAR- DASAR TARI TRADISIONAL BALI}

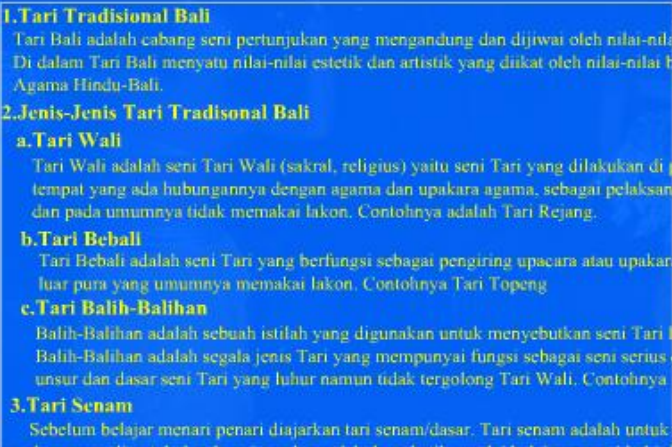

KETUAR

Gambar 2.Tampilan Menu Utama Multimedia Gerakan Dasar Tari Bali

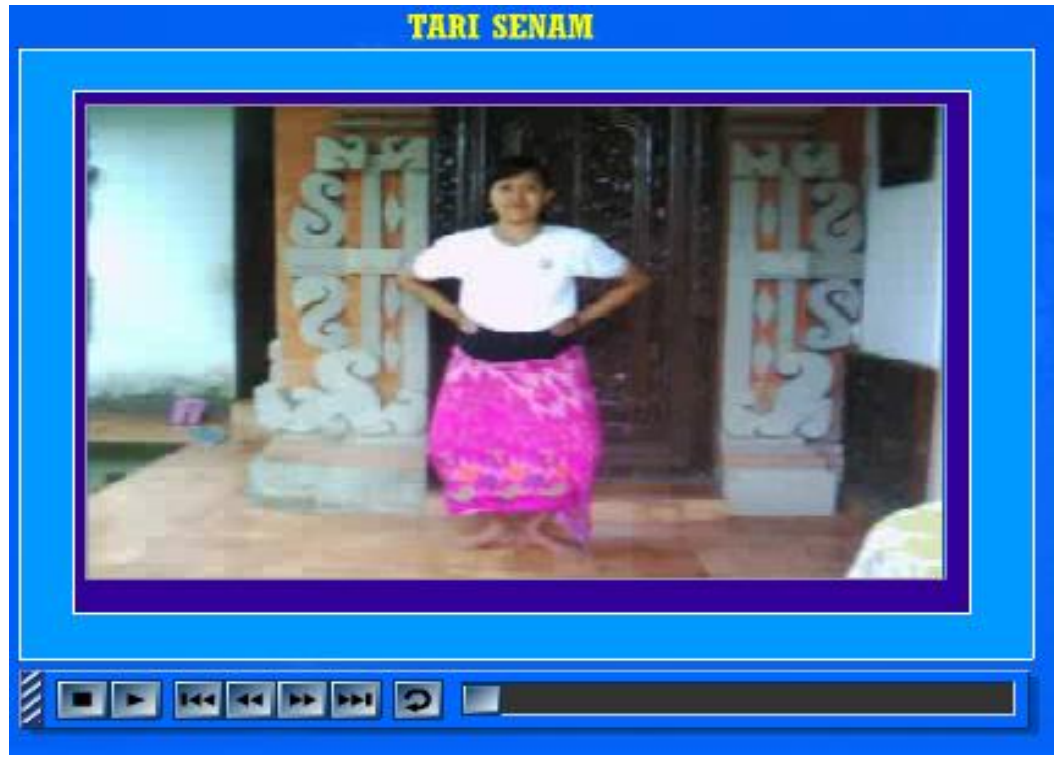

Gambar 3. Tampilan Menu Gerakan Tari Senam 


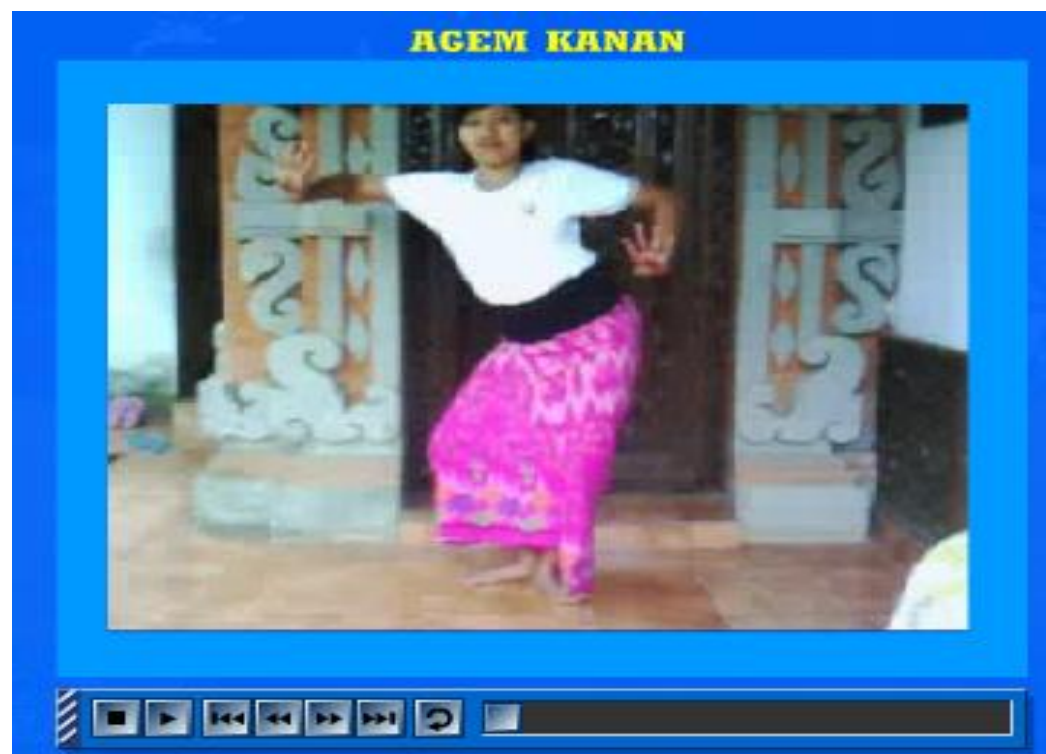

Gambar 4. Tampilan Menu Gerakan Agem Kanan

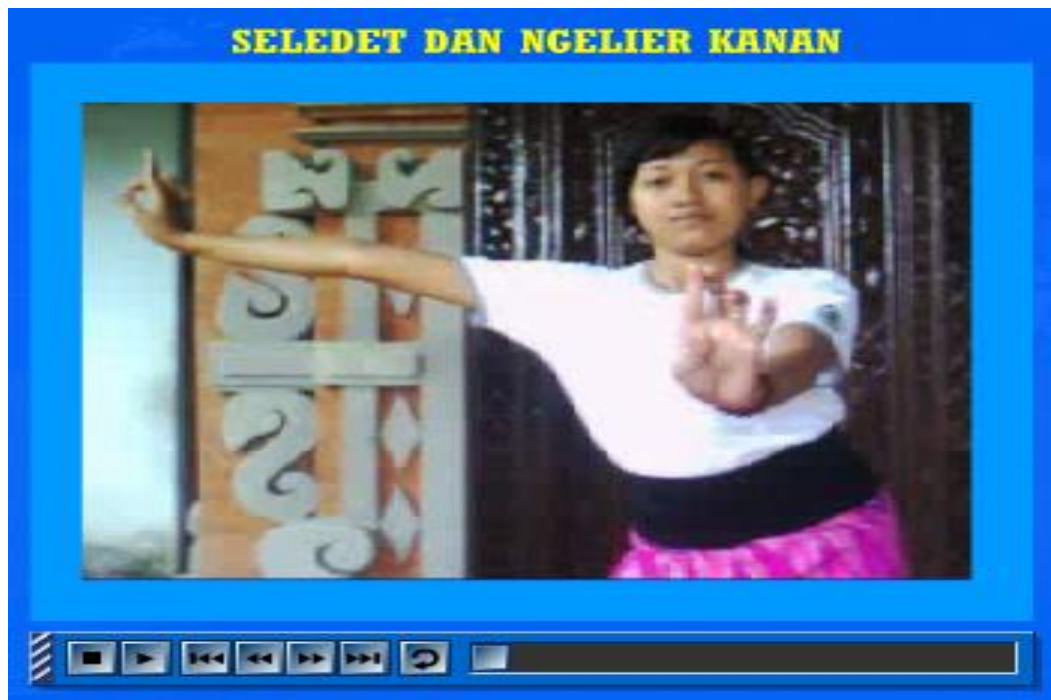

Gambar 5. Tampilan Menu Gerakan Tandang (Seledet dan Ngelier Kanan) 


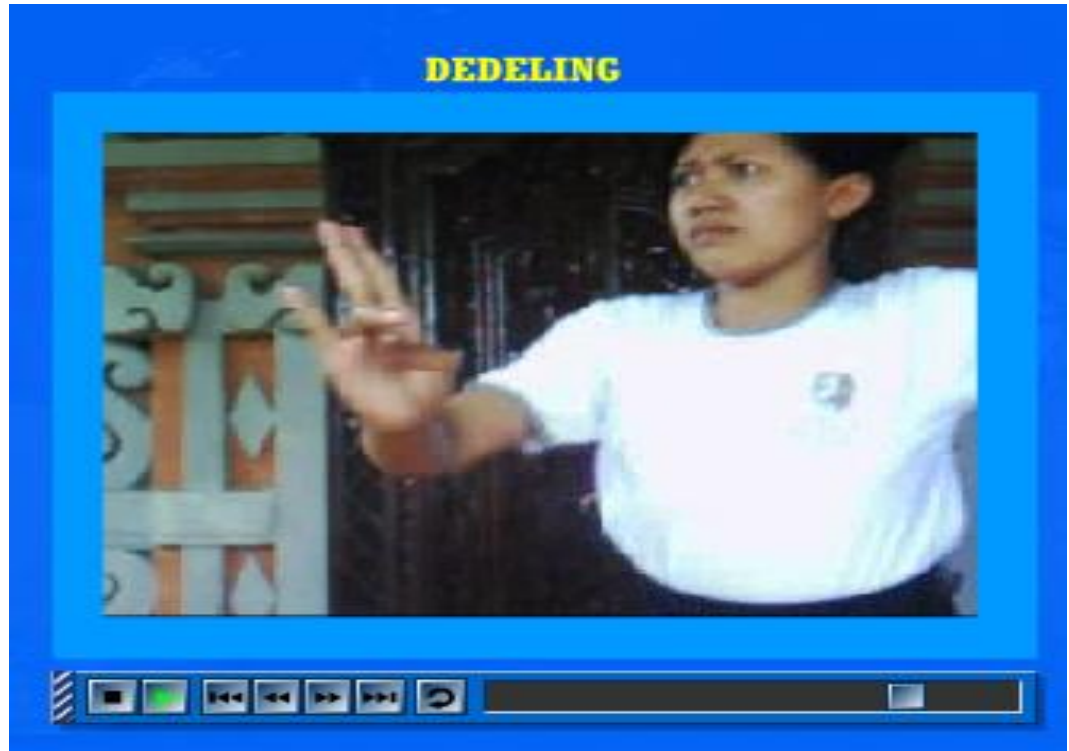

Gambar 6. Tampilan Menu Gerakan Tangkep (Dedeling)

\section{PENUTUP}

Untuk meningkatkan kualitas penari khususnya untuk tarian Bali, terlebih dahulu harus mempelajari grakan dasar tari Bali. Untuk membantu siswa belajar secara mandiri gerakan dasar tari maka diperlukan media. Dengan adanya pengembangan multimedia gerakan dasar tari Bali, maka siswa dapat mengulang gerakan-gerakan dasar tari Bali secara mandiri di berbagai tempat dan waktu yang tak terbatas sehingga siswa dapat melakukannya dengan mudah.

Pada media ini yang dikembangkan hanya sebatas pada contoh gerakan dasar yaitu agem, tandang dan tangkep yang ditampilkan dengan sangat sederhana dan pengambilan gambar masih belum sempurna. Untuk itu perlu pengembangan berikutnya agar dapat menghasilkan media yang lebih sempurna. Selain itu juga dapat dikembangkan jenisjenis tarian tradisonal yang ada di Bali. 


\section{PUSTAKA}

Amel. "Pengaruh Sistem Pembelajaran Berbasis Multimedia Terhadap Penyerapan Materi Oleh Peserta Didik". Tersedia pada http://littleamenk.blogspot.com/2009/05/pengaruh-sistempembelajaran-berbasis.html (diakses tanggal 19 Januari 2010).

Arsyad, Azhar, M.A. 2005. Media pembelajaran. Jakarta: PT RajaGrafindo Persada.

Bandem, I Made. 1983. Ensiklopedi Tari Bali. Denpasar: Dinas Kebudayaan.

Bandem, I Made., dkk. 1985. Pengembangan Tari. Denpasar: Akademi Seni Tari Indonesia (ASTI) Denpasar.

Fadil Mohammad. "Pemanfaatan Media untuk Proses Pembelajaran yang Efektif dan Menyenangkan”. Tersedia pada http://mfadil.blog.unej.ac.id/ pemanfaatan-media-pembelajaran (diakses tanggal 19 Januari 2010) 